\title{
Teaching Foreign Language for Specific Purposes in Terms of Professional Competency Development
}

\author{
Dmitry L. Matukhin \\ Associate Professor, Dept. of Foreign Languages, Institute of Power Engineering, \\ Tomsk Polytechnic University, Tomsk, Russian Federation \\ Email:mdlbuddy@mail.ru \\ Elena N. Gorkaltseva \\ Senior Lecturer, Dept. of Foreign Languages, Institute of Power Engineering, \\ Tomsk Polytechnic University, Tomsk, Russian Federation \\ Email: elena_gork@mail.ru
}

\section{Doi:10.5901/mjss.2015.v6n1p525}

\section{Abstract}

\begin{abstract}
The paper is the result of generalizing personal and colleagues' professional teaching experience as well as conducting the detailed content analysis of the data on teaching methods of foreign language for specific purposes (ESP). Basically masters' and doctorate theses of the last decade have been chosen in the function of analysis references as all of them either explicitly or implicitly reveal the given issues as the target or subject of scientific research. The paper puts forward a problem of professional development of foreign language (FL) teaching to students of various majors and revision of its role in the achievement of personhood of the future specialist. Thus, the main goal of teaching foreign language is considered to be developing the communicative competency so that a trainee will be able to socialize, share experience and solve communication challenges in the context of intercultural professional communication. The purpose of the article is to clearly highlight the main trends in exposing contemporary problems of teaching foreign language for specific purposes and to emphasize the achievements in this area of knowledge.
\end{abstract}

Keywords: language for specific purposes, competency, speech activity, educational technologies, educational materials.

\section{Introduction}

Modern Russian society is characterized by transparency to the outside world, expanding the scope of communication with representatives of the world in the field of professional activity, and implementing the spiritual needs. Consistent implementation of the Bologna Process in Russian higher education offers significant advantages in terms of expanding opportunities for international cooperation in science and education and full participation in the international educational space, which is an essential condition for a high level of education in terms of foreign languages.

One of the trends of educational paradigm now is competency building approach, which involves the development of a person's ability to apply existing knowledge and skills to solve specific practical problems. An important condition for the implementation of this approach is the development of professional foreign language communicative competency. Therefore, in Russian education there is a transition from the concepts of "preparedness" and "knowledge" to the concepts of "competence" and "competency". Pedagogical interpretation of foreign language communication involves the development of the ability to understand similarities and differences between native culture and other qualities in order to develop intercultural-oriented personality, characterized by a polyphonic vision of the world and tolerance mentality.

Possessing great educational potential, the subject of "Foreign Language for Specific Purposes" in higher educational institutions solves the problem of personality development and ensures systematic replenishment of professional knowledge, formation and development of communicative skills. A strategy for improving the content and methods of teaching ESP involves the development of a holistic approach to solving problems on the basis of theoretical study and experimental verification of learning technologies. With today's variety of methods of teaching foreign languages there is a selection problem of the most effective technologies and prospects of solving the problems of developing professional communicative competency (Matukhin, Nizkodubov et al, 2014)

Exploring the standards of higher education in recent years, it should be noted that there is the increased level of 
foreign language proficiency requirements for the students of non-linguistic faculties, not only in terms of the ability to produce professional information, but also the ability to exchange information at the understandable level for recipients. In this case, the analysis of such skills in practical terms allows us to identify insufficient level of development of communication skills. From this it follows that there is a need for such an organization process of teaching foreign languages, which would encourage integrating didactic, psychological, linguistic, socio-cultural and methodological tools that contribute to the successful development of professional communicative competency (Shaturnaya, 2009).

\section{Objectives of the Study}

The purpose of teaching language for specific purposes shall be to achieve the level sufficient for its practical use in the future professional activity. Professionally-oriented training provides professional focus not only on educational content, but also the activities of developing professional skills. Modern graduate is expected not just to be able to read and translate professional texts, but also use foreign language in various fields of communication.

Thus, the objectives of the study were to:

- summarize first-hand and faculty members' professional experience in teaching foreign language;

- carry out explicit content analysis of the scientific papers on teaching methods of foreign language for specific purposes;

- cover the main tendencies in exposing pressing issues of teaching ESP and to emphasize the breakthroughs in the given field of expertise.

\section{Review of Literature}

Obraztsov (2005) by language for specific purposes training means teaching based on the needs of students in foreign language learning, set by the peculiarities of their future profession or specialty which, in turn, demand ESP learning. Thus, the concept of professionally-oriented foreign language teaching lies in its integration with professional disciplines in order to obtain additional professional knowledge and develop professionally significant qualities of a person.

Language for specific purposes training consists in developing professional communicative competency that would enable to carry out professional contacts in a foreign language in various fields and situations. The scope of communication is regarded as a set of homogeneous communicative situations characterized by uniformity of speech stimulus, relations between the communicants and communication environment (Kalmikova, 2006).

According to Makar (2000), foreign language can be not only the subject of mastering, but also a means of developing professional communicative competency. This involves the expansion of the concept of professional orientation of foreign language teaching, which includes another component - professionally-oriented focus of the content of educational material. Professionally-oriented training provides professional focus not only on educational content, but also activities, including methods and techniques that develop the professional skills.

Professional orientation of activities:

- requires integration of the discipline of foreign language with the majors;

- poses the problem of teaching future professionals based on interdisciplinary connections to apply foreign language as a means of regular replenishment of their professional knowledge, as well as means of developing professional skills;

- involves the use of teaching methods and modes capable of developing necessary professional skills of the future specialist (Roginko, 2010).

Considering FL as means of developing professional orientation of the future specialist, Roshchina (2008) notes that the study of professionally-oriented language material establishes two-way communication between the desire of students to acquire professional knowledge and success of language learning. Moreover, FL is an effective means of professional and social orientation in the technical university, which has great potential of formative influences.

Teaching language for specific purposes, in order to successfully develop professional communicative competency, requires a new approach to the selection of content. Galskova (2000), Graboy (2002) state that the content of ESP teaching should include then:

- scope of communicative activities, themes and situations, speech acts and speech material, taking into account the professional orientation of students;

- linguistic material (phonetic, lexical, grammatical, orthographic), its presentation rules and skills of operating 
them;

- set of special (verbal) skills that characterize the level of practical mastery of a foreign language as a means of communication, including in situations of professional and business communication, joint production and research;

- system of knowledge of national and cultural characteristics and realities of the foreign language country.

\section{Research Methodology}

Waiver of subject-centered approach in education in favor of integrative approach contributed to the fact that the majority of educators in higher professional schools not only recognize but in practical terms accept the idea of each subject contribution to the common strategic goal - to train demanded skilled professionals capable of adapting to the labor market conditions. The key indicator is professional competencies. Its basic development in higher school is aimed at improving students' skills to manage consciously and intelligently their social behavior (Collier, 2008; Lier, 2006). Great contribution to developing mental flexibility, updating professional mobility when solving specific problems in the context of single international educational space and globalization processes in all areas, including professional one, is made by specific language training of students - future professionals (Munby, 2009; Nunan, 2000). For example, Dunaeva (2006) has undertaken an investigation of the didactic potential of embedded information environment on the material of teaching foreign language as a means of scientific communication. Gudkova (2002) in theoretical and methodical terms substantiated feasibility of embedded teaching materials "Linguistic means for information systems", which reflect integration of specialist disciplines such as "basic theory of formal languages", "language of automated information systems" and the discipline of "English language".

Rich linguistic and cultural heritage of Europe is seen as a valuable common resource that should be protected and promoted. At the same time the idea that diversity of languages should become an instrument of mutual enrichment and understanding has been formulated (Appadurai, 2003; Houston, 2000). The logical consequence of this fact was a problem statement of linguistic training professionalization for students of language faculties and reconsideration of its contribution to the socialization of a future professional, especially in the field of translation.

Then educators are focused on strengthening professional guidance of language courses provided by the curriculum in different specialties and majors. Therefore, the problem extends to create linguistic and communicative competency at a level that would be sufficient for the subject of education to continue their training activities, study foreign experience in their majors, technology and solution of communicative problems in the situations of cross-cultural professional communication (Jenniskens, 2002; Lier, 2006).

In this regard, modern pedagogy can distinguish a special branch of scientific work and experimental studies aimed at identifying the most effective conditions for creation and improvement of various competencies through teaching language for specific purposes: universal competencies - Mikhanova (2008); social competency - Andreeva (2008); communicative competency - Graboy (2002); cross-cultural competency - Gubina (2004). Results of the undertaken content analysis of the theses allowed drawing a conclusion that there are two opposing tendencies within the specified area. On the one hand, the trend of integration, according to which the growing importance of dual competency created by learning a foreign language as a second specialty is substantiated. However, there is a trend of disintegration, i.e. traditionally single language competency undergoes some fragmentation, e.g. Krasnova (2010) discusses the creation of lexical competency in mastering Russian as a foreign language for special purposes, Bobodzhanova (2008) reveals the way of creating foreign language grammatical competency, taking into account national and cultural characteristics of the target language in the field of professional communication.

The important role of language for specific purposes in the context of competency-based approach is also due to the fact that this academic discipline develops and improves personally and professionally meaningful competency qualities of the future specialists: specific professional skills - Ermakova (2003); culture of professional/business crosscultural communication - Abaeva (2003); readiness for future professional activities - Lapshina (2004); axiological qualities - Olejnik (2003); world view building, including professional - Pankratova (2004).

The second important area of educational research in the field of teaching language for specific purposes is creation and improvement of learning technologies, namely, the way they contribute to development of students' careeroriented skills. Information technologies which occurred at the peak of popularity in the late 90s of the last century, gradually withdrew the list of so-called revolutionary innovations, but didn't lose its relevance. Currently, these technologies are directly related to the objectives of creating the integrated educational environment and are considered as one of the means to achieve other goals of education, in particular, they are integrated with other learning 
technologies (Widdowson, 2003; Wilkinson, 2001; Willis, 2001). Level of students' skills to practice foreign language as a means of professional communication depends on IT adequacy to professionally-oriented content of teaching a foreign language.

Issues of practical implementing project-based technology into teaching language for specific purposes are considered in the scientific paper by Kobylskaya $(2008)$ and Savingon $(2001,2007)$. It was revealed that this technology, on the one hand, is attractive not only because of its novelty, but also integrative potential. On the other hand, it is more conducive to the development of professionally significant qualities of engineering students. The results of empirical studies by the abovementioned authors show that project-based technology meets the personal and professional expectations of engineering students as well as develops teamwork skills. This applies particularly to educational telecommunications projects. Therefore, their implementation into teaching language for specific purposes is considered to be effective.

Test technologies are also within the field of linguodidactic research. Herewith, their role in foreign language learning is determined, focused on professional communication and multifunctionality, by Kartseva (2007). Marco (2002) discloses an approach of using hypertext technology in teaching foreign language for specific purposes. Interactive methods of teaching foreign language for specific purposes to students based on professional texts are described in the thesis by Roginko (2010). Issues of modular education intended for developing professional and business communication are investigated in the scientific work by Sokolova (2007). Role playing is still of great interest for educators. Various issues of applying business role plays in teaching professionally-oriented foreign language communication are studied by Shaturnaya (2009).

Another important issue in teaching foreign language for specific purposes is associated with developing and improving learning materials. Most experts in teaching methods of foreign languages associate the solution to this problem with the development of appropriate specialized courses. A great deal of attention is paid to scientific and methodological substantiation of their structure and content in connection with the design of integrative courses (Kanunnikova, 2005) for certain specialties, as well as in connection with the universities transition to Bachelor degree programs. The most popular target audience is future economists, educators, lawyers, and environmentalists. Identifying the linguodidactic basics for creating relevant textbooks should be mentioned among the achievements of modern language pedagogy. Despite the fact that many educators, implementing syllabi for the courses of "Foreign language for specific purposes" and "Professional foreign language" clearly prefer authentic teaching materials, problem of creating domestic learning materials does not lose its relevance. Thus, Stolyarova (2009) offered her view of a textbook on business cross-cultural communication for the language higher schools. Some of the proposed materials can be adapted to the teaching language for specific purposes to the students of non-language faculties.

The role of electronic teaching resources is increasing due to irreversible trends, such as computerization of society as a whole and technologization of professional education system. This was reflected in a large number of scientific papers. For example, analysis of these trends in terms of the existing regulations and the results obtained in the course of specific scientific research was undertaken (Matukhin, Nizkodubov, Zyubanov, Khasanshin, Obskov, 2014); organization benefits of the quality assessment of professional language training for students based on electronic teaching materials were revealed (Igna, 2010). In order to conduct successful assessment, it's necessary to embed widely computer technologies in the learning process, create computer learning environment and special conditions for the development of students' independent study (Matukhin, Evseeva, 2014)

Scientific papers by Kobylskaya I.I., Sidorenko T.V., Cherkashina O.A. and many others are dedicated to creating electronic teaching aids. Herewith, the necessity to consider the specific pedagogical technology that underlies its application in foreign language learning is emphasized.

The ideas of Levonisova S.V., Lavrentieva O.A. and other researchers are noteworthy as they are dedicated to the use of auxiliary references, in particular, computer dictionaries, schematic aids, etc. Scientific view on the teaching methods of foreign language for specific purposes to students in the light of teaching language aspects or certain types of speech activity is another big trend in the language pedagogy. Priorities are as follows. Most educational theses are devoted to investigating reading materials, then come speaking and writing. Let's describe it in more detail.

First of all, they are doctoral research dedicated to the contribution of various types of reading, for example, skim reading - Agapitova (2000), extensive reading - Zhirkova (2004), professionally-oriented reflexive reading - Krylova (2008). Moreover, the types of texts used in reading, mostly authentic for specific purposes, are discussed by L.N. Filimonova, S.L. Mertsalova, descriptive texts - T.E. Korchagina, memoir texts - E.N. Anokhina. Widdowson (2001) offers a method of teaching multi-language abstracting of texts for specific purposes.

Much attention is paid to the methodical organization of work for the purpose of text interpretation. This is a multifaceted process that is associated with the need to develop a set of verbal, technical, educational and informational, and 
organizational skills. Malyavina (2002) developed a set of exercises for professionally-oriented teaching foreign language interpretation of a literary text to the higher school students, Bazarova (2008) proposed a solution of a similar problem based on the matter of professional texts.

Mastering the language side of text materials for reading is a separate methodological problem. Lexical and grammatical aspects of reading are considered by different authors in different ways. Tannen (2005) seeks to ensure the expansion of students' potential vocabulary while reading authentic texts for specific purposes. Poeckl (2000) justifies the ways of teaching students the understanding of emotive vocabulary while reading literary texts. Westhoff (2000) suggests the ways to overcome grammatical difficulties in teaching reading texts for specific purposes, Kovtun and Kuprikowa (2000). successfully tested a method of developing the structural and compositional skills of foreign language professionally-oriented reading by interpreters in terms of business communication. Methods of analyzing syntactic constructions while reading texts for specific purposes, based on a three-phase model, is described in the paper by Hutchinson and Waters (2007).

Speaking training and its strategies in the situations of professionally-oriented communication as well as improvement of monologue and dialogue communication skills are investigated in the doctoral theses by Pshenichnova (2007), P.A. Sidorenko, O.V. Chuksina and others. Research conducted by means of 'interdisciplinary' approach is always of great interest. For example, implementation of an integrated approach to teaching reading and speaking based on the text types for specific purposes can be observed in the papers by N.V. Gagarina (2010), Hampden-Turner (2000), Hulstijn (2000) and others.

However, along with the existing achievements there are some drawbacks in investigating the teaching methods of foreign language for specific purposes, which are associated with a low share of scientific papers devoted to the issues of teaching professionally-oriented listening and writing. As regards listening, such papers are extremely rare, but their target audience is mostly foreign students - Watkins (2005), Jackowski (2000) and others. As for teaching writing as a kind of speech activity, almost all the problems are surveyed on the material of writing a business letter; therefore the important issues of professionally-oriented text creating remain outside of linguodidactics. Furthermore, many studies are implemented within philological instead pedagogical sciences. The situation is similar with regard to the problems of developing professional thesaurus.

\section{Conclusion}

Thus, summing up the results of the personal teaching experience and the data of the undertaken content analysis of scientific educational surveys, it can be concluded that investigating the issues of teaching language for specific purposes in the modern higher professional school is carried out within the number of major research areas - competency, technology, resource, and content. The achievements clearly show the important role of language/foreign language learning in the process of training modern professionals and didactic potential of the subject area of "foreign language" within the integrative model of the higher professional education. Nevertheless, there are still some important issues that require further research and methodological studies.

\section{References}

Abaeva, F.B. (2003). Development of intercultural communication skills in teaching business English. PhD thesis (Education), Vladikavkaz.

Agapitova, T.G. (2000). Teaching foreign language skim reading when developing professional culture of the future teacher of a foreign language. PhD thesis (Education), Perm.

A Memorandum on Life-Long Learning (2000). Working Group "Education and Training Statistics" Meeting. November 13-14, Eurostat/E3/2000/ETS02.

Andreeva, L.N. (2008). Developing social competency of the future engineers in the process of learning foreign languages in technical universities. PhD thesis (Education), Cheboksary.

Appadurai, A. (2003). Modernity at Large. Cultural Dimensions of Globalization. USA: University of Minnesota Press.

Bazarova, T.I. (2008). Methods of teaching students-philologists professional interpretation of texts in the foreign language classes. PhD thesis, Nizhny Novgorod.

Bobodzhanova, L.K. (2008). Developing foreign language grammatical competency based on national and cultural peculiarities of the studied language in the field of professional communication. PhD thesis (Education), St. Petersburg.

Bologna: The European Higher Education Area (2005). The Bologna Declaration. Joint declaration of the European Ministers of Education. URL: http://www.bologna-bergen2005.no/Docs/00-Maindoc/990719BOLOGNADECLARATION.PDF (3.5/2006).

Collier, M., Thomas, M. (2008). Cultural Identity: an Interpretive Perspective. Theories of Intercultural Communication. Newbury Park, Calif.: Sage, 109-122. 
Dunaeva, L.A. (2006). Didactic integrated information environment for foreign students of Humanities, studying the Russian language as a means of scientific communication. Doctorate thesis (Education), Moscow.

Employability in the Context of the Bologna Process (2005). General Conclusions and Recommendation. URL: http//www.bolognabergen2005.

Ermakova, Yu.D. (2003). Developing professional skills of students of a pedagogical college in the process of learning a foreign language for specific purposes. PhD thesis (Education), St. Petersburg.

Gagarina, N.V. (2010). Methodical system of training reproductive and productive speaking based on the text types for specific purposes. PhD thesis (Education), Tula.

Galskova, N.D. (2000). Modern methods of learning a foreign language: A guide for teachers. Moscow: ARKTI Glossa.

Graboy, T.A. (2002). Developing professional communicative competency based on the materials of language for specific purposes in non-language higher school. PhD thesis (Education), Moscow.

Gubina, N.M. (2004). Developing intercultural competency of students in the process of teaching business English within a special elective course (advanced level, specialty "World Economy"). PhD thesis (Education), Moscow.

Gudkova, S.A. (2002). Designing and implementing the technology of developing professional competency of programmers in the process of learning a foreign language in a college. PhD thesis (Education), Togliatti.

Hampden-Turner, Ch., Trompenaars, F. (2000). Building Cross-Cultural Competence. USA: Yale University Press.

Houston, W.R., Howsam, R. (2000). Competency-based teacher education. Progress, Problems and Prospects. Chicago: Science Research Associates.

Hulstijn, J.H. (2000). The Use Of Computer Technology In Experimental Studies Of Second Language Acquisition: A Survey Of Some Techniques And Some Ongoing Studies. Language Learning \& Technology. Vol. 3, No. 2, 32-43.

Hutchinson, T., Waters, A. (2007). English for specific Purposes: a learning-centered Approach. Cambridge: Cambridge University Press.

Ideas and Resources for Teachers (2002). Integrating Technology into Planning and Curriculum. Corp. Seale V. Last updated: June 13, 69-77.

Igna, O.N. (2010). Technical development as a modern trend of the language professional and pedagogiacal training. Bulletin of Tomsk State Pedagogical University. Issue 1, 135-140.

Jackowski, P. (2000). Auditive Komponente in den Übungen zum Hörverstehen: Analyse ausgewählter DaF-Lehrwerke für Grundstufe. Colloquia Germanica Stetinensia, 297-308.

Jenniskens, I., Maassen, P., Huisman, J., Yossensteyn, A., Kaiser, F., De Boer. H. (2002). Management and Decision Making in Higher Education Institutions. A Guide, Netherlands: Lemma Publishers.

Kalmikova, L.I. (2006). Professionally-oriented interconnected training of all kinds of foreign language speech activity in the technical universities. Perm.

Kanunnikova, N.V. (2005). Linguodidactic principles of designing an integrative course of teaching a foreign language to the students of economic specialties of higher educational institutions. PhD thesis (Education), Tomsk.

Kartseva, I.R. (2007). Polyfunctionality of language intercultural communication. PhD thesis (Philosophy), Kazan.

Kobylskaya, I.I. (2008). Project-based methodology of teaching English to engineering students based on electronic teaching materials. PhD thesis (Education), Moscow.

Kovtun, L.G., Kuprikowa, T.S. (2000). English for Bankers and Brokers. Managers and Market Specialists, Moscow.

Krasnova, S.V. (2010). Developing lexical competency of foreign students in mastering the Russian language for specific purposes. PhD thesis (Education), Moscow.

Krylova, S.A. (2008). Methods of teaching professionally-oriented reflexive reading to the $1^{\text {st }}$ and $2^{\text {nd }}$ year students of historical specialties in the teacher training university. PhD thesis (Education), Moscow.

Lapshina, G.A. (2004). Developing readiness for self-education of the future teachers of a foreign language. PhD thesis (Education), Elec.

Lier, L. (2006). Interaction in the Language Curriculum. Awareness, Autonomy and Authenticity. London.

Makar, L.V. Teaching professionally-oriented English language communication to technical learners. PhD thesis, St. Petersburg.

Malyavina, A.N. (2002). Professionally-oriented teaching interpretation of the fiction texts to students of foreign language major. PhD thesis, Togliatti.

Marco, M.J.L. (2002). Internet Content-based Activities for English for Specific Purposes. English Teaching Forum Magazine. USIA. Vol. 40. No. 3, 13-16.

Matukhin, D.L., Nizkodubov, G.A., Zyubanov, V.Y., Khasanshin, Y.R., Obskov A.V. (2014). Methodological Basics of Blended Learning in Teaching English for Academic Purposes to Engineering Students. Asian Social Science. Vol. 10, 97-102. URL: http://dx.doi.org/10.5539/ass.v10n20p97

Matukhin, D.L., Evseeva, A.M. (2014). Further Professional Training as a Constituent Part of Continuing Vocational Education. Lecture Notes in Management Science. 2nd International Conference in Humanities, Social Sciences and Global Business Management (ISSGBM 2014). June 21-22, London, UK. Vol. 31, 104-109.

Mikhanova, O.P. (2004). Creating and developing universal competencies of higher school students in the process of learning a foreign language: non-language majors. PhD thesis (Education), Penza.

Munby, J. (2009). Communicative Syllabus Design. Cambridge: Cambridge University Press.

Nunan, D. (2000). Syllabus Design. Oxford. 
Obraztsov, P.I. (2005). Design and construction of professionally-oriented training technology. P.I. Obraztsov, A.I. Ahulkova, O.F. Chernichenko. Orel.

Olejnik, E.E. (2003). Developing spiritual and moral values of domestic pedagogical culture of the future teacher in the process of learning a foreign language. PhD thesis (Education), Ryazan.

Pankratova, E.A. (2004). Developing legal world view of the law students by means of a foreign language. PhD thesis (Education), N. Novgorod.

Poeckl, W. (2000). Kontrastive Textologie. Ein Projektuntemcht. Zeitschrift ftir Interkulturellen Fremdsprachenunterricht. URL: http://wvyw.ualberta.ca/ german/eiournal/poeckl.htm

Pshenichnova, E.N. (2007). Teaching foreign students to Russian professionally-oriented business communication. PhD thesis (Education), Moscow.

Roginko, E.V. (2010). Interactive methods of teaching students foreign language professional communication based on the text types for specific purposes. PhD thesis (Education), Moscow.

Roshchina, E.V. (2008). Functions of the foreign language as a subject in the university education system. Foreign languages for nontechnical faculties. St. Petersburg: Publishing House of St. Petersburg University Press.

Savignon, S.J. (2002). Communicative Curriculum Design for the 21st Century. English Teaching Forum Magazine. USIA, Vol. 40. No. 1, 3-7.

Savingon, S.J. (2007). Communicative Competence. Theory and Classroom Practice. McGraw Hill, 237-240.

Shaturnaya, E.A. (2009). Methods of teaching foreign language professional discourse by means of training-speech situations and roleplaying. PhD thesis (Education), Tambov.

Sokolova, L.N. (2007). Modular organization of the educational process for the development of professional and business communication skills. PhD thesis (Education), Novocherkassk.

Stolyarova, I.N. (2009). Linguodidactic basics of a textbook on business intercultural communication for language higher school. PhD thesis (Education), Ulan-Ude.

Tannen, D. (2005) The handbook of discourse analysis. Maiden: Blackwell Publishing.

The Quality of Vocational Training (2000). European Commission, Directorate-General for Education and Culture. Brussels, November.

Watkins, P. (2005). Learning to Teach English. Delta Publishing.

Westhoff, G. (2000). Fertigkeit Lesen. Fernstudieneinnheit. Muenchen.

Widdowson, H.G. (2001). English for Specific Purposes: Criteria for Course Design In English for Academic and Specific Purposes: Studies in Honor of Louis Trimbler. Newbury House.

Widdowson, H.J. (2003). Learning Purposes and Language Use. Oxford: Oxford University Press.

Wilkinson, J. (2001). Designing a New Course. Teachers and Learners in Action: The Society for Research into Higher Education \& Open University Press. Buckingham.

Willis, J. (2001). Teaching English through English. Longman handbooks for language teachers. Longman Gr. Ltd.

Zhirkova, O.P. (2004). Teaching methods of fiction extensive reading in the process of training German for students of the second language specialty in the teacher training university. PhD thesis (Education), Vladimir. 